\title{
The Effects of the Use of the Know-Want-Learn Strategy (KWL) on Fourth Grade Students' Achievement in Science at Primary Stage and Their Attitudes towards it
}

\author{
Najeh Rajeh Alsalhi ${ }^{1 *}$ \\ ${ }^{1}$ Ajman University, UNITED ARAB EMIRATES
}

Received 26 August 2019 - Revised 30 November 2019 • Accepted 9 December 2019

\begin{abstract}
This study aimed at investigating the effects of KWL strategy in fourth grade students' achievement in science and their attitudes towards using it. It compares the results of different ways of teaching science topics, and students' attitudes towards their use. The study was conducted using a quasi-experimental design case study. The participants of the study were 62 students, divided into two groups: one an experimental group ( $n$ $=31$ ) and the other a control group $(n=31)$. An achievement test and questionnaire were designed to confirm the study's validity and reliability. SPSS was used to analyze the data. The findings revealed that there were statistically significant differences between the experimental and the control groups, in favor of the experimental groups' and attitudes, were also more positive towards the using of KWL strategy. The study recommends further research into using the KWL strategy in primary stage education.
\end{abstract}

Keywords: attitudes, KWL strategy, primary stage, science teaching, science achievement

\section{INTRODUCTION}

One of the most important features of the twenty-first century in which we live today is the rapid and astonishing development of knowledge and technology, particularly in terms of scientific knowledge within the various areas of science and its branches. This requires us to keep pace with this development, especially in the field of teaching science and the strategies and methods used for teaching students. We know that the role of education is to act as a support in ensuring the nation's progress. According to Steele and Dyer (2014), in recent years, education and curriculum experts have implemented and experimented with new and innovative strategies and teaching methods on an ongoing basis with a view to improving the quality of education.

As the science curriculum is directly related to our daily lives, experts and curriculum designers have demonstrated an increasing interest in the science curriculum and methods used for teaching it in order to provide students with scientific knowledge in a functional way that enables them to apply science effectively in their daily lives.

Hayes (2002) and Munck (2007) point out that teachers in schools must have the knowledge and ability to enhance students' achievement by using modern teaching strategies and methods. Zouhor, Bogdanović, Skuban, and Milica (2017) confirm that the use of appropriate teaching strategies and methods of teaching is directly related to the achievements of students during their studies. In addition to that, Ekwensi, Moranski, and Townsend-Sweet (2006) point out that the teachers must modify their teaching strategies in order to help students acquire and understand knowledge effectively. Nagel, Blignaut, and Cronjé (2009) said that in general, weak students interact and participate less than stronger students, thus teachers should increase their level of collaboration via discussion, in order enhance their understanding and thereby improve their critical thinking skills. Many researchers and educational experts have pointed out that renewal and modernization of the methods and strategies used in teaching the curriculum has become an urgent necessity and a vital requirement in order to find a balance between fast living in the age of globalization and the role that educational systems should play.

(c) 2020 by the authors; licensee Modestum Ltd., UK. This article is an open access article distributed under the terms and conditions of the Creative Commons Attribution License (http://creativecommons.org/licenses/by/4.0/). $\square$ n.alsalhi@ajman.ac.ae (*Correspondence) 


\section{Contribution of this paper to the literature}

- This study examines an important research point in terms of experimenting with the effectiveness of one of the metacognitive strategies of the constructivist learning theory in teaching science.

- Kwl may be one of the strategies that can be used by science teachers to improve student achievement.

- KWL strategy identifies important implications for teaching practice.

\section{Education in the United Arab Emirates}

The United Arab Emirates, in its quest to achieve leadership from a major pillar, is building the human being, and for that purpose, it has laid the foundations and rules for building this human being, foremost of which is an education in its comprehensive and integrated sense. Education in the UAE is currently undergoing a stage of positive development and progress. The National Agenda for Vision 2021, was launched by UAE government, aims at learning and education for a first-rate education system. To become that all schools, universities in UAE equipped with the latest educational tools, modern technology, and smart systems and that the educational curricula at the highest level of scientific content. Moreover, provide and qualify educational leaders qualified academically and educationally licensed in accordance with the latest international standards (UAE Vision, 2021). This development of the United Arab Emirates (UAE)'s educational system is closely aligned with social changes that have been brought on by the rapid economic growth of the state.

In fact, the development began in 2015, where the Ministry of Education in UAE was worked to develop its system from technology, curricula, textbooks, methods of education and assessment strategies. In addition, unified national learning standards have been developed to guide the process of teaching and learning to ensure that the personality of the learner is developed in terms of knowledge, values, and skills (Ministry of Education, 2015).

Now, UAE students daily continue to show improved scores in international education assessments conducted like Trends in Mathematics and International Science (TIMSS) study and The Programme for International Student Assessment (PISA). these positive and improve results of students came by using teachers of science and mathematics in UAE the modern teaching strategies by adapting to modern educational theories like constructivism theory, and Metacognition theory through application the strategies education the directly related to these theories.

\section{Metacognition}

The strategy of metacognitive thinking is one of the best-known strategies in this regard. Moreover, it is important for learning science. The term "metacognition" refers to "one's knowledge concerning one's own cognitive processes and products" (Flavell, 1976, p. 232).

In addition, Kuhn and Dean (2004) point out that metacognition is the awareness and management of one's own thoughts. According to Schraw and Moshman (1995), metacognitive knowledge includes the following aspects: declarative knowledge, which refers to how to do something; procedural knowledge, which covers the skills, strategies and resources required to perform a task, i.e. knowledge of how to perform something; and conditional (strategic) knowledge, which refers to knowledge of when to apply a certain strategy.

The know-want-learn strategy is considered one of the metacognitive strategies, and in its shortened form, 'KWL', it refers to: What do I Know? - What do I Want to learn? - What did you Learn? Donna Ogle developed KW-L in 1986. Since its origin, the KWL strategy has been used as an instructional reading strategy.

As a reading strategy, it helps new teachers engage students from the beginning of a reading lesson by activating prior knowledge. KWL also helps teachers keep students interested as they think about what they want to know and what they have learned (Sasson, 2008). Since originally it was a reading strategy, it was rarely applied in teaching science. However, it became a simple and effective strategy that can be applied in different school subjects (Foote, Vermette, \& Battaglia, 2001). In addition, Bryan (1998) and Ogle (2009) stated that the use of the KWL strategy supports both active and student-centered learning. Blachowicz and Ogle (2008) said that KWL consists of three phases in which students: (1) activate prior knowledge; (2) determine what they want to know; and (3) reflect on and recall new knowledge. Blachowicz and Ogle (2008) said that the KWL strategy consists of three basic stages: (1) accessing previous knowledge; (2) determining what one wants to know; and (3) recalling what is learned. Gammill (2006) emphasized that the use of the KWL strategy makes learning and remembering easier and enhances students' ability to understand topics such as those related to science. This view was shared by Jared and Jared (1997), who said that KWL encourages complete understanding of a topic, since students study a specific question that they are interested in. In recent decades, researchers have focused on the problem of students' inadequate reading and studying habits (Taslidere \& Eryilmaz, 2012), which leads to them being unwilling to study science 
Table 1. Main columns of the KWL

\begin{tabular}{|c|c|c|}
\hline Topic of content (Title): & & \\
\hline Before you start learning, in & in the first two columns aft & his, fill in the last column \\
\hline What I Know & What I Want to Learn & What I Have Learned \\
\hline$\underline{\mathbf{K}}$ & $\mathbf{W}$ & $\mathbf{L}$ \\
\hline 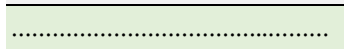 & 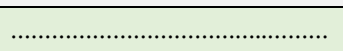 & 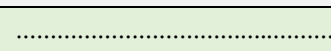 \\
\hline 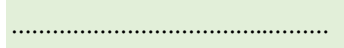 & 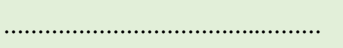 & (1) \\
\hline 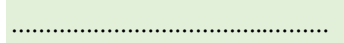 & 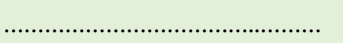 & 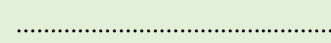 \\
\hline 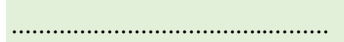 & . & . \\
\hline
\end{tabular}

and to them having difficulty in understanding it (Hewitt, 1990). Accordingly, many researchers have pointed out that KWL may be a good learning strategy for acquiring science knowledge.

\section{Know-Want-Learn strategy (KWL Strategy)}

The KWL strategy was introduced in 1986 by Ogle as a simple, active and powerful reading strategy (Foote et al., 2001). According to Camp (2000), it deepens students' understanding of topics they find in textbooks, and then, after the reading process, increases their knowledge and helps them organize and arrange the information they have understood. Siribunnam and Tayraukham (2009) pointed out that the KWL strategy generally concentrates on analytical reading through encouraging students in the classroom to use their thinking skills. Stahl (2008) pointed out that KWL is a procedure conducted by the teacher involving creative discussion about the topic of the lesson, followed by the use of papers, charts or a class board to record student information about what they know $(\mathrm{K})$, want to learn $(\mathrm{W})$ and finally what they have learned (L). In Blachowicz and Ogle (2008) explain the procedures that the teacher and his or her students undertake in the KWL strategy, where the teacher firstly starts by using brainstorming with reading and teaching together, with the aim of discovering what they know already about the lesson, which refers to the' 'K' (what the students Know) in the KWL strategy. Secondly, the teacher begins to encourage his/her students through guiding them to examine and check their knowledge data about the topic of the lesson, and to find other data or partial data related to what they know about the subject they are learning. Thus, the teacher's role is just to write on the board his/her students' knowledge statement data and their ideas about what think they know, and the students' role of thinking of real questions. Therefore, the teacher's main role is to encourage his/her students and motivate them to think about what they should learn, which refers to the ' $W$ ' (what the students Want to know) in the KWL strategy. Then, thirdly, students write or fill out what they have learned in the classroom in the ' $L$ ' column, making sure they focus specifically on the questions and categories that have been developed, paying particular attention to information related to what they want to know. Ibrahim (2012) confirmed that the KWL strategy encourages the activity of reading for students through activating, arranging and organizing students' previous background knowledge, which leads, finally, to students being able to sum up and reflect on what they have learned by using KWL charts. According to Zouhoret al. (2017), the know-want-learn (KWL) strategy suggests using a graphical organizer that helps students organize their information before, during and after a topic, a lesson or even a unit. In addition, it is an instructional scheme that develops active reading of texts by activating learners' background knowledge.

The KWL chart consists of three main columns, which are First Column: K - What I Know; Second Column: W - What I Want to Know; Third Column: L - What I Have Learned as shown in Table 1 (Abu Youniss, 2013; Ogle, 2005; Tok, 2008).

Szabo (2006) summarized the objectives of using the KWL strategy as follows.

(1) Through brainstorming, students activate their previous knowledge about the subject of the lesson, thereby increasing their interest and motivating them to understand.

(2) The students can limit what they want to study and their questions about the topic, which increases their reading and hence their understanding.

(3) The KWL strategy helps students' self-learning by monitoring their understanding and development and finally their ability to evaluate their learning.

(4) The KWL strategy gives students the opportunity to expand their ideas and their understanding about the topic.

Further, Conner (2006) emphasized that the use of the KWL strategy through several activities will encourage the students to use it as an independent learning strategy to activate their prior knowledge, and it helps them set a definite aim for reading and recording what they have learned. Furthermore, there are modified KWL strategies where charts are modified for different student activities. For example, KWL Plus where the concept mapping and summarizing of learned content is added to the original strategy (Ogle, 1987). KWLH where the H- indicates how I can learn more (Weaver, 1994). KLEW(S) where K-What do we think we Know, L- What are we Learning (claims, 
E-What is our Evidence, W-What do we still Wonder about and S - What Scientific principles help explain the phenomena. (Hershberger, Zembal-Saul, \& Starr, 2006; Hershberger \& Zembal-Saul, 2015.

\section{Previous Studies}

Extensive studies have been conducted about the use of KWL in education. The results of these studies showed that the achievement of students who were taught by applying the KWL strategy was improved in positive form comparing by the traditional method. Where there was a statistically significant difference between the marks of the students' in the experimental group and the students' of the control group in the achievement test in favour of the experimental group. Which confirmed that the KWL strategy has a positive impact on student achievement (Akily, 2010; Araam, 2012; Kishta, 2008; Lismayanti, 2014; Sinambela, Manik, \& Pangaribuan, 2015; Siribunnam \& Tayraukham, 2009; Tok, 2008; Zouhor et al., 2017). Other studies indicate that through the implementation of the KWL strategy, students are encouraged to be mentally active during the learning process, makes the learning of concepts and topics remembering easier, develop appropriate questions for a particular topic and develop their skills in organizing their prior knowledge of the subject and evaluating their success in learning. KWL strategy can, therefore, be considered as a metacognitive strategy (Gammill, 2006; Ogle, 2005; Taslidere \& Eryilmaz, 2012; Tok, 2008). Accordingly, it is necessary to introduce new teaching strategies during teaching the contents of the science textbook, like the KWL strategy, which is a metacognitive thinking strategy that can be a good learning strategy for acquiring the scientific concepts, laws, and theories, and understanding it.

Thus, through a review of previous literature, the present study differs from previous studies in that it is one of the rare studies examine more than one variable, academic achievement, students attitudes, and its impact on the independent variable (use of KWL strategy) and traditional learning.

\section{Study Purpose}

The study was conducted with the purpose of examining the effect of using the KWL strategy to improve students' achievement in science and the attitudes of students' in the experimental group towards using KWL strategy.

\section{The Study Significance}

The importance of the research can be summarized as follows:

- The results of the study can be of interest to curriculum developers as well as those who are interested in science education, by providing them with recommendations about the use of KWL as a new strategy in science teaching.

- It develops teaching methods for science teachers using modern teaching strategies such as the KWL strategy.

- It develops the ability of students linking previous information learned to new information.

- Can benefit researchers in teaching science from the results and recommendations.

\section{Study Problem and its Questions}

The interest of the Ministry of Education in the UAE on the importance of using teachers' to the active and suitable teaching methods that have a direct relationship with students' achievement.

Thus, the study problem emerged by urgently needed of the educational sectors to study the impact of using KWL strategy in the teaching of science in addition to identifying the attitudes of students towards using it, especially in the primary stage. The results from a number of previous studies showed the effectiveness of the KWL strategy on academic achievement (Siribunnam \& Tayraukham, 2009; Tok, 2008; Zouhar, Bogdanović, Skuban, \& Milica, 2017).

Thus, in order to do so, this research asks the following research questions:

RQ1. What is the effect of using KWL strategy on improving Students' Achievement in science subject for the fourth grade at the primary stage?

RQ2. What are the Students' attitudes in the experimental group towards using KWL strategy in teaching science? 


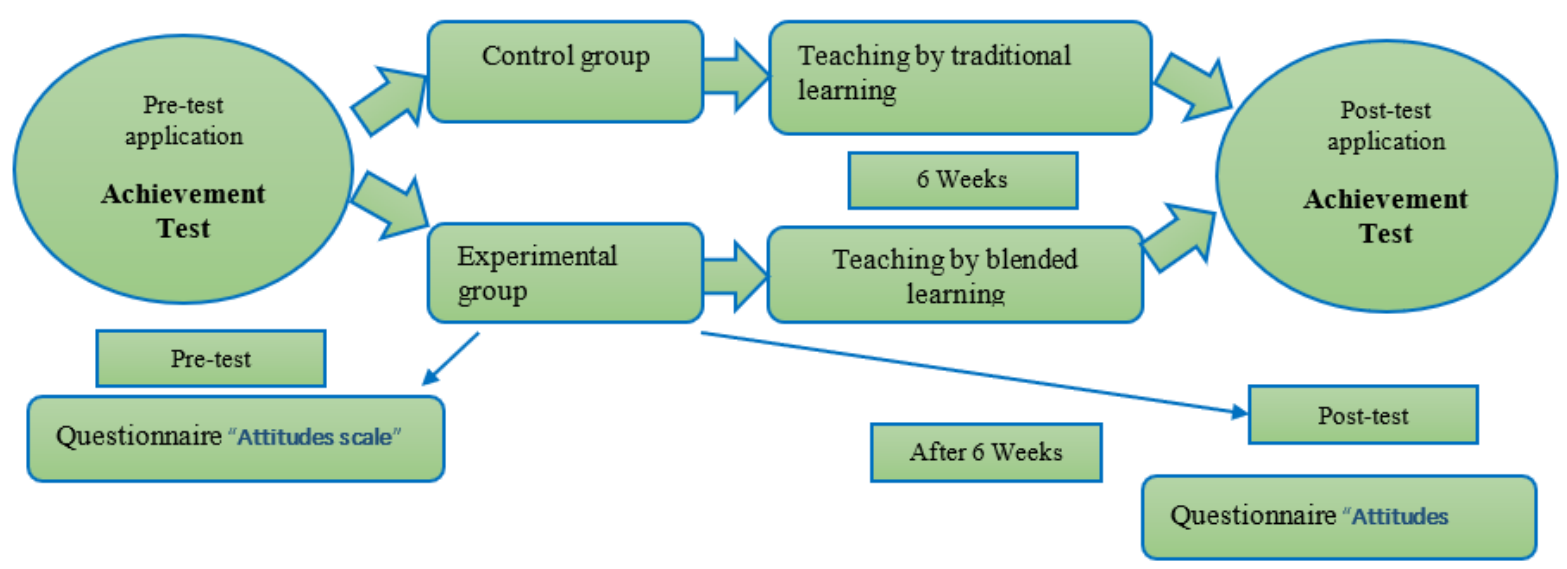

Figure 1. Experimental design of the study

\section{Study Hypotheses}

- There were no statistically significant differences between the mean scores of the experimental group who used the KWL strategy in their studies and the mean scores of students in the control group who studied the traditional education, in the post-achievement test.

- There are no significant attitudes among students in the experimental group towards the use of KWL strategy in science teaching before and after the application of it.

\section{Study Terms}

- KWL strategy: Defined by Camp (2000) as a strategy that is based on the reader's knowledge of a subject, what the reader wants to know and what the reader has learned at the end of the reading process, and one in which the information is arranged graphically. Moreover, according to Piper (1992), the KWL technique is a common method used by teachers to help students activate their schema prior to reading, improve comprehension during reading and organize their thoughts following reading. In addition, Kopp (2010) pointed out that it is a new strategy used by teachers to activate students' thinking about the subject of the lesson before the new learning occurs.

- Students' academic achievement: This is the result of what students learn and includes learning outcomes after the learning process at all levels of knowledge according to Bloom's classification of educational goals (Aloraini, 2012).

- Effect: the Nair and Bindu (2016) point that; the effect is the change that results when something happens: an event, situation, or situation resulting from a particular cause.

- Attitudes: Defined by Christo-Baker (2000) as the negative or positive feeling towards a state or a fact. The attitude also defines by Ajzan (1988) the considers attitudes as "a disposition to respond favorably or unfavorably to an object, person, institution, or event" (p. 4).

- Fourth- Grade: all the students studying during the first semester of the year 2018/2019.

\section{METHOD}

\section{Study Approach}

The quasi-experimental approach was used in this study in order to examine the effect of the KWL strategy on primary school students' achievement in science, due to its suitability to the nature of the study See Figure 1 explain the quasi-experimental design of the study:

The students in the control group were taught Unit 2 (Kingdoms of Living Things) of the fourth-grade science textbook using traditional teaching, while in the experimental group the students were taught the same Unit 2 (Kingdoms of Living Things) of the fourth-grade science textbook using the KWL strategy. In other words, the same unit was taught to the students in both groups for the same time during the first semester of the academic year 2018/2019. The teaching topics in the unit taught during the research are presented in Table 2.

The teacher took an active part in preparing the material and completed the necessary preparation in order to use the KWL strategy in teaching students. 
Table 2. The teaching topics in the unit Kingdoms of Living Things

\begin{tabular}{|c|c|c|}
\hline Name of the unit & Topics & Pages \\
\hline \multirow{2}{*}{ Kingdoms of Living Things } & Lesson 1: Cells & $18-35$ \\
\hline & Lesson 2: Classification of living organisms & $36-57$ \\
\hline \multicolumn{2}{|c|}{ Total number of pages } & 40 \\
\hline
\end{tabular}

Table 3. Demographic information for participants

\begin{tabular}{cccc}
\hline Group & N & Level & Learning Method \\
\hline Experimental & 31 & Primary & KWL strategy \\
\hline Control & 31 & Primary & Traditional Learning \\
\hline Total & 62 & & \\
\hline
\end{tabular}

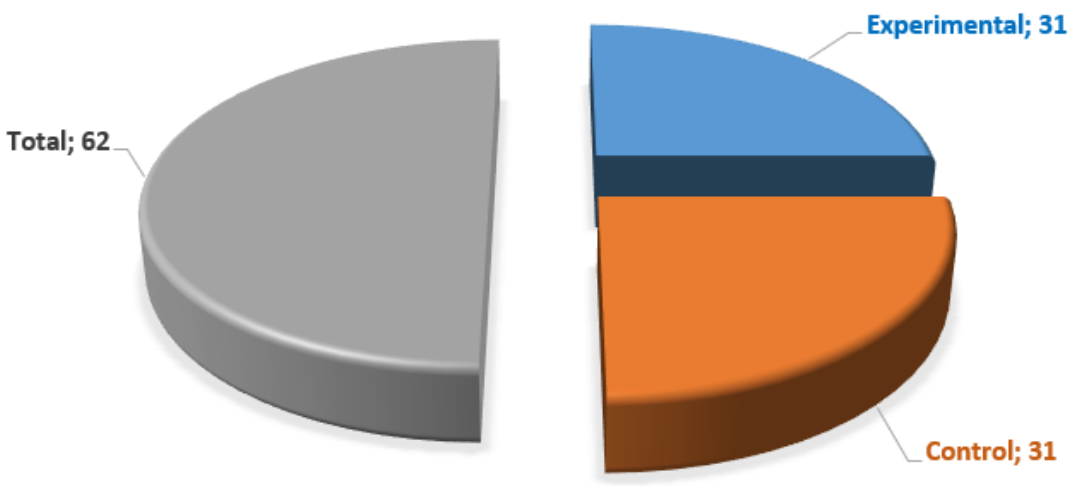

Figure 2. Demographic information for participants

\section{Study Participants}

The participants of the research consisted of 62 female fourth-grade students. Who were divided into two groups, an experimental group consisting of 31 students and a control group consisting of 31 students, at the Abu Obaida Bin Jarrah Private School in the Ajman zone in the United Arab Emirates, during the first semester of the academic year 2018/2019, as shown in Table 3 and Figure 2.

\section{Study Variables}

- Independent variables which are the two teaching method :

a) KLW strategy

b) traditional method

c) Pre-test (before intervention)

d) Post- test (After intervention)

- Dependent Variables: the science achievement scores of students of study groups measured on two occasions(Pre-test \& Post-test) and responses of the experimental group on their attitudes toward of learning science using KWL strategy.

\section{Study Tools}

The researcher reviewed previous studies and literature related to the subject of the research, such as the studies of Zouhor et al. (2017), Lismayanti (2014), Siribunnam and Tayraukham (2009) and Tok (2008). After that, the researcher prepared the tools, which was the following:

\section{Achievement test}

Achievement test for the second unit (Kingdoms of Living Things) of the fourth-grade science textbook, which consists of 20 multiple-choice questions, each with four options, one of which represents the correct answer and the total score of the exam is 20 marks. The test was prepared according to Bloom's taxonomy of cognitive domains (Hyder \& Bhamani, 2016). The testing time was 45 minutes. 
Table 4. The Evaluation of Scale Data Based on the Options of Scale and Score Intervals

\begin{tabular}{ccc}
\hline Options & Scores & Score Intervals \\
\hline Very high & 5 & $4.21-5.00$ \\
\hline High & 4 & $3.41-4.20$ \\
\hline Moderate & 3 & $2.61-3.40$ \\
\hline Little & 2 & $1.81-2.60$ \\
\hline Very little & 1 & $1.00-1.80$ \\
\hline
\end{tabular}

Examples of questions of the achievement test:

Q1: The basic unit of structure and function in living things is the...

a) nucleus. b) membrane. c) cell. d) chloroplast.

Answer (c).

Q2: Oxygen is carried throughout the body by ...

a) white blood cells. b) red blood cells. c) guard cells. d) bone cells.

Answer (b)

Q3: Phototropism shows the two characteristics of living organisms?

a) growth and nutrition. b) growth and sensitivity.

c) movement and nutrition. d) nutrition and sensitivity.

Answer (b)

Validity of Achievement Test: The achievement test was confirmed by the virtual validity method by submitting it in its initial form to the jury members of the teaching staff at the universities whose doctorate and master's degree holders in curricula and methods of teaching science. Deleted was of some questions and add other questions according to their recommendation and suggestions even the test became valid.

Reliability of Achievement Test: The researchers verified the reliability of the achievement test by using the test-retest method. Through applied the test on a sample reconnaissance of 24 students from another school in the same area, and two weeks after giving the test was re-applied to the same sample of students, after that the Pearson correlation coefficient between the two applications was calculated, where the total reliability coefficient (0.84) was considered appropriate for the purposes of this study.

\section{Questionnaire}

A questionnaire was designed to collect data from 31 students of the experimental group about their attitudes toward using KLW strategy during they learn science topics. The questionnaire consisted of (20) items belonging to the purpose of the study.

Data Collection questionnaire Validity: The validity of the questionnaire was confirmed by the Virtual Validity method, after obtaining permission from the Deanship of Graduate Studies and Research, by checking the validity of the content. A group of arbitrators, comprising experts in the fields of methods of teaching science and psychology were asked to express their opinions in terms of the appropriateness of items to achieve the objectives of the study and the number of items and comprehensiveness.

Data Collection questionnaire Reliability: The researchers verified the questionnaire reliability by conducting a pilot study involving 20 students from another school in the same area and calculated the Cronbach's alpha coefficient for the entire questionnaire through SPSS which was (0.811).

Data Analysis Measures: A five-dimensional Likert scale is adopted in this study as follows: very high (5), high (4), moderate (3), low (2) and very low (1), with the options used to evaluate counting periods. Responses were then categorized into equal five range levels through the following equation: the length of category $=($ maximum value - minimum value $) \div$ number of alternatives $=(5-1) \div 5=0.80$, as shown in Table 4 .

\section{Pre-test}

In order to examine the equivalence of the achievement in science of the two groups in the study, the researcher used a t-test to compare the results of the pretest of the topics of the science textbook unit, before applying the KWL strategy as shown in Table 5. 
Table 5. T-test results of pretest between the experimental and the control groups

\begin{tabular}{ccccccc}
\hline Group & N & Mean & Std deviation & T. value & Sig. (tailed) & Sig. level \\
\hline Pre-control & 31 & 13.90 & 1.66 & \multirow{2}{*}{0.161} & \multirow{2}{*}{0.874} & $\begin{array}{c}\text { Not } \\
\text { Significant }\end{array}$ \\
\hline Pre-experimental & 31 & 14.00 & 1.05 & & &
\end{tabular}

Statistically significant at $(p<0.05)$

Table 6. T-test result of differences between the experimental and the control groups in the post-test

\begin{tabular}{|c|c|c|c|c|c|c|}
\hline Group & $\mathbf{N}$ & Mean & Std deviation & T. value & Sig. (tailed) & Sig. level \\
\hline Post-control & 31 & 15.00 & 0.816 & \multirow{2}{*}{4.385} & \multirow{2}{*}{0.000} & \multirow{2}{*}{ Significant } \\
\hline Post-experimental & 31 & 16.90 & 1.100 & & & \\
\hline
\end{tabular}

Statistically significant at $(p<0.05)$

As shown in Table 5, since the obtained $p(0.874)$ is greater than 0.05 , the test is not significant at 0.05 level which indicates that there is no significant difference between the two groups of study (experimental group and control group). This revealed that the experimental and control groups were equivalent before the study could be applied.

\section{Preparation of scientific textbook manual using KWL strategy}

A guide was prepared in accordance with the KWL strategy to serve as a guide for the teacher in taking the lessons of the targeted science units in the research. After completing the manual, the guide was tried out using the KWL strategy, by a science teacher on a sample reconnaissance of students from another school close to the area. The experiment and the level of student interaction were evaluated based on the application of the KWL strategy and then the necessary adjustments were made.

\section{Application of study tools}

The study tools were applied after the completion of the teaching of the experimental and control group to verify the validity of the hypothesis of the study.

\section{Statistical Treatments}

The researcher used the SPSS program to answer the research questions. Through calculated the arithmetic means and standard deviations, T-test Independent sample was used to measure the statistical differences in means between the experiential and the control groups in the results of the post-test. In addition to used Paired Samples t-test to the comparison of experimental group Students' Pre-application and Post-application Mean scores of the KWL strategy attitudes scale.

\section{RESULTS AND DISCUSSION}

\section{Study Findings Related to RQ1}

The question was: What is the effect of using KWL strategy on improving Students' Achievement in science subject for the fourth grade at the primary stage?

To answer the $R Q 1$, the following null hypotheses were tested:

There were no statistically significant differences between the mean scores of the experimental group who used the KWL strategy in their studies and the mean scores of students in the control group who studied the traditional education, in the postachievement test.

In order to verify the hypothesis, the difference between the mean scores of students in the experimental group and the control group in the science achievement post-test was calculated using a t-test for two independent samples. The results are shown in Table 6 and Figure 3. 


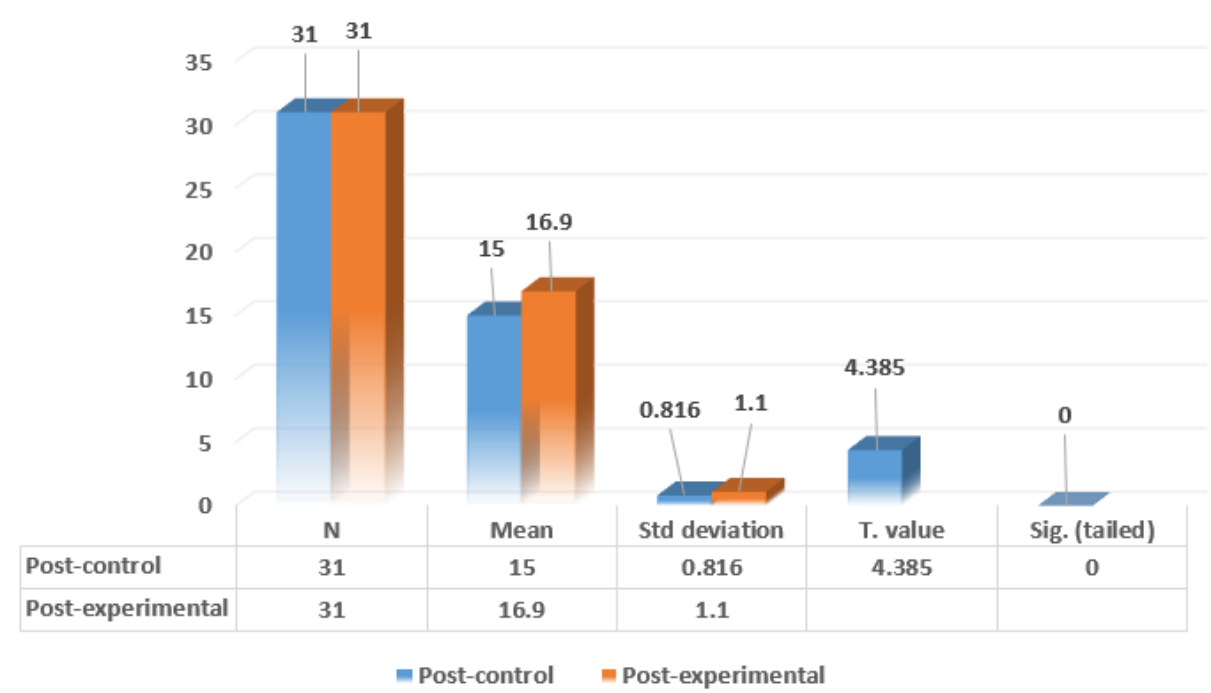

Figure 3. T-test result of differences between the experimental and the control groups in the post-test

Table 7. Means and standard deviations of Pre-application and Post-application for experimental group on attitudes scale towards using KWL strategy

\begin{tabular}{cccc}
\hline Experimental Group & N & Mean & Std. Deviation \\
\hline Post-application & 31 & 3.97 & 0.42692 \\
\hline Pre-application & 31 & 2.58 & 0.85729 \\
\hline
\end{tabular}

The results in Table 6 and Figure 3 indicate that the $t$ computed value was 4.385. This is larger than in the $t$ table, and p-value (0.000) is smaller than 0.05 , which means there are significant differences at the significance at 0.05 level which indicates that there is a significant difference between the mean scores of the control group and the experimental group in the science textbook post-test, in favour of the experimental group.

The mean score of the experimental group was 16.90 in the post-achievement test, while the mean score of the students in the control group was 15.00 in the post-achievement test. This indicates the superiority of the experimental group in the post-test scores of students who learned using the KWL strategy, thereby rejecting the zero hypothesis.

This indicates, the experimental group during 6-weeks was taught using the KWL strategy, whereas the control group was taught by traditional learning. This means rejecting the null hypothesis. Based on the results of the test, it can be concluded that the teaching of female students topics science through KWL strategy, has a positive effect on improving Students' Achievement in the science topics.

\section{Study Findings Related to RQ2}

The question was: What are the Students' attitudes in the experimental group towards using KWL strategy in teaching science?

To answer the $R Q 2$, the following null hypotheses were tested:

"There are no significant attitudes among students in the experimental group towards the use of KWL strategy in science teaching before and after the application of it"

To determine whether there is a difference between the results of the experimental group's students regarding their attitudes towards the use of KWL strategy in their teaching the topics of science content before and after application, paired samples t-test was applied to the pre-application and post-application scores of the KWL strategy attitude scale. As the results obtained are shown in Table 7 and Figure 4. 


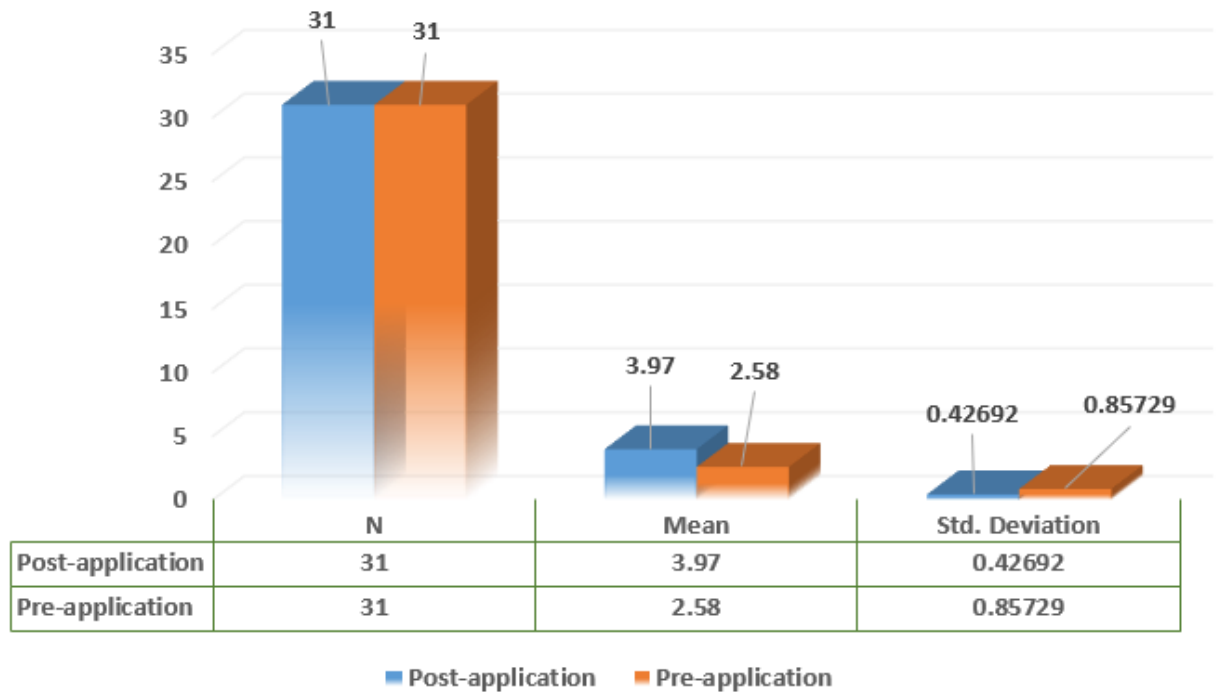

Figure 4. Means and standard deviations of Pre-application and Post-application for experimental group on attitudes scale towards using KWL strategy

Table 8. Comparison of the experimental group Students Pre-application and Post-application Scores Mean of the KWL strategy attitude scale via the Paired Samples t-test

\begin{tabular}{|c|c|c|c|c|c|c|c|c|}
\hline Experimental Group & $\mathbf{N}$ & Mean & Mean Differences & Std. Deviation & $\mathbf{t}$ & df & Sig. (2-tailed) & Sig. level \\
\hline Post-application & 31 & 3.97 & \multirow[t]{2}{*}{1.39} & 0.42692 & \multirow[t]{2}{*}{-12.286} & 30 & \multirow{2}{*}{0.000} & \multirow{2}{*}{ Significant } \\
\hline Pre-application & 31 & 2.58 & & 0.85729 & & & & \\
\hline
\end{tabular}

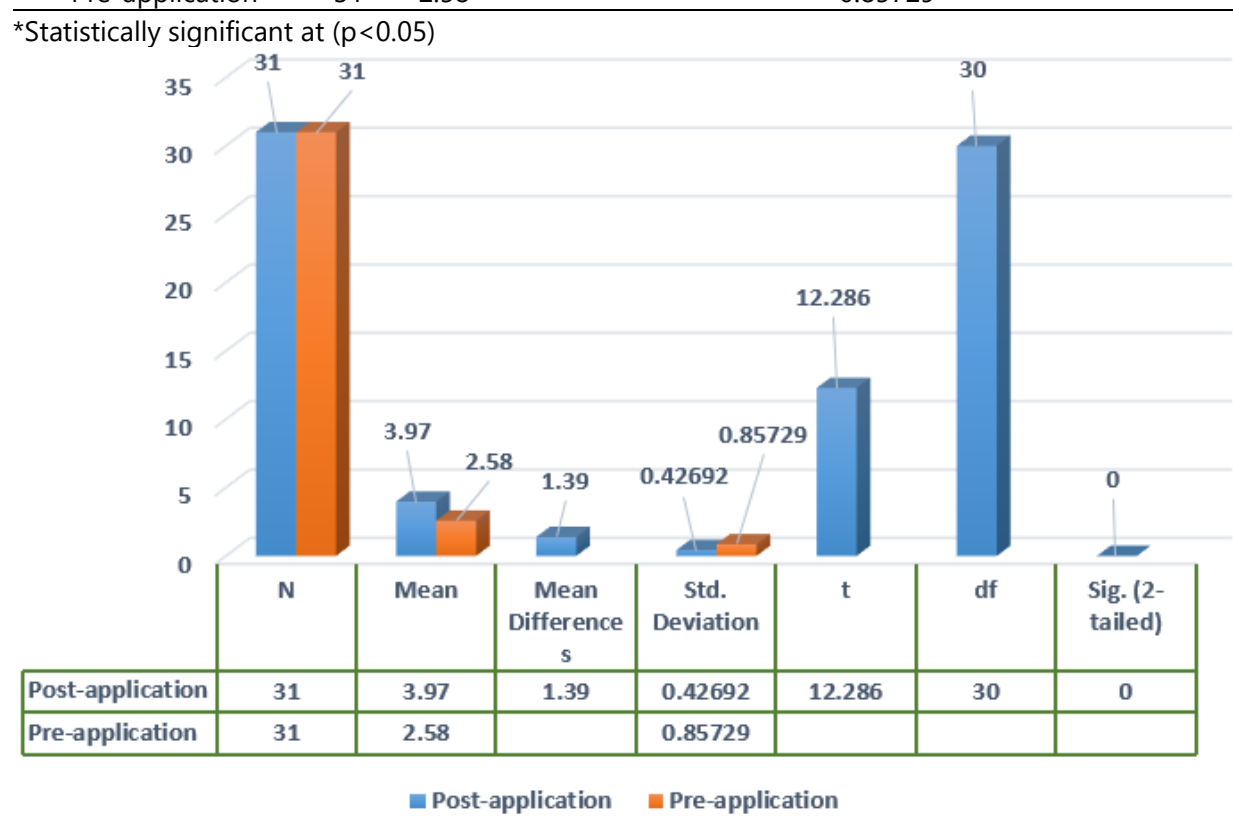

Figure 5. Comparison of the experimental group Students Pre-application and Post-application Scores Mean of the KWL strategy attitude scale via the Paired Samples t-test

According to result in Table 8, and Figure 5 it is seen that there was a significant difference $(\mathrm{t}(30)=12.286, \mathrm{p}$ $<.05)$ between the experimental group students' Post-application mean (3.97) and their Pre-application mean (2.58). This means rejecting the null hypothesis.

Based on this finding, it can be confirmed that there are positive attitudes towards the use of KWL strategy into the learning of the topics of science content by experimental group students. 


\section{DISCUSSION}

The obtained results concerning the first research question, regarding the effect of using KWL strategy on improving Students' Achievement in science subject for the fourth grade at the primary stage, indicated that there was a significant difference between students of the experimental and the control groups, in favor of the students in the experimental group. If we examine the results shown in Table 6 and Figure 3, we find that the average of post-test scores, for students in the experimental group, is 16.90 , compared to 15.00 for the control group. This means we can conclude that KWL strategy has a positive impact on the achievement students of the experimental group when compared to traditional learning on the students of the control group. Also, the results showed as, in Table 6 and Figure 3, there are significant differences at the significance at 0.05 level where p-value was equal $(0.000)$ and smaller than 0.05 , which indicates that there is a significant difference between the two groups of learners with regard to their understanding the unit topics of Kingdoms of Living Things. This indicates that teaching using a KWL strategy has a positive effect on the achievement in science of students from the experimental group compared to the traditional method of the control group. The finding is consistent with several earlier studies that also confirmed the positive impact of KWL strategy on the achievements of students (compared to traditional learning) (Araam, 2012; Akily, 2010; Kishta, 2008; Lismayanti, 2014; Siribunnam \& Tayraukham, 2009; Sinambelaet al., 2015; Tok, 2008; Zouhor et al., 2017). Therefore, the current study, as well as the reviewed studies, prove that the KWL strategy has a positive effect in terms of increasing the academic achievement of students. In brief, the use of the KWL strategy in teaching adds an element of interaction. This is demonstrated by the participation of students of the experimental group during different stages of the teaching process, in collecting what the students know about the topic, then what they want to know about it, and then the students have the ability and skills to write down all the new information they have learned about this particular topic.

The second research question concerned the attitudes of students of the experimental group towards using KWL strategy. To answer this question, the null hypothesis was tested:

Firstly, we postulated that there would be no statistically significant differences between the mean scores of the experimental group, and those of the students in the control group, in the post-achievement test. We applied a scaled questionnaire to the students in the experimental group before they began using the KWL strategy (preapplication) and re-applied it again, after 6 weeks of training (post-application). We applied a paired samples t-test to the pre- and post-application scores of the KWL strategy attitude scale.

The results shown in Tables 7, 8 and Figure 4, 5 show that the average of pre- and post-applications was 3.97, compared to the pre-application scale (where the average was 2.58). Additionally, there was a significant difference $(\mathrm{t}(30)=12.286, \mathrm{p}<.05)$ between the experimental group students' post-application mean (3.97) and their preapplication mean (2.58). The null hypothesis was therefore rejected and our results confirmed that there the experimental group held positive attitudes towards the use of KWL strategy. This finding is consistent with prior studies (Akkoyunlu \& Soylu, 2008; Bonk \& Graham, 2006; Gammill, 2006; Ja'ashan, 2015; Ogle, 2005; Osguthorpe \& Graham, 2003; Shahin, 2008; Taslidere \& Eryilmaz, 2012; Tok, 2008). Conversely, the study's results do not agree with some other earlier studies whose results found no significant differences in attitudes towards the use of KWL strategy among students (Al Shdifat, 2015) in which the results came moderately.

\section{CONCLUSION}

That education in the United Arab Emirates is witnessing rapid positive changes and developments in all areas reflecting life in the United Arab Emirates. United Arab Emirates Ministry of Education is trying to use modern methods of education to teach students in their primary and secondary schools and encourages their teachers to develop their teaching skills in order to increase students' academic achievement. The results of this study show that the application of KWL strategy had a positive impact on students' achievement. There was a statistically significant difference between the experimental and the control groups, in favor of the experimental group, who were taught using KWL strategy. Moreover, the students in that group had positive attitudes toward the use of KWL strategy. These results were in agreement with previous studies that confirmed the positive impact of KWL strategy on the achievement of students and their positive attitudes towards its use (Akkoyunlu \& Soylu, 2008; Akily, 2010; Araam, 2012; Bonk \& Graham, 2006; Gammill, 2006; Ja'ashan, 2015; Kishta, 2008; Lismayanti, 2014; Ogle, 2005; Osguthorpe \& Graham, 2003; Siribunnam \& Tayraukham, 2009; Shahin, 2008; Sinambela et al., 2015; Taslidere \& Eryilmaz, 2012; Tok, 2008; Zouhor et al., 2017).

This study is important because it shows that KWL strategy is effective in education, especially in the primary stage. This means education can be more effective if the advantages of the KWL strategy environment are integrated with face-to-face interaction in the classroom. 


\section{RECOMMENDATIONS}

In the light of the results, the researcher makes the following recommendations:

- Teachers should be encouraged to employ cognitive thinking strategies in their teaching due to their effectiveness in developing knowledge and students' skills.

- It is necessary for the system of assessment and evaluation in schools to be modified to suit the KWL strategy by the curriculum designers and decision-makers in the Ministry of Education in the UAE.

- Teachers' abilities in teaching science should be improved by holding training courses to encourage the use of modern and innovative strategies like the KWL strategy.

- The system of assessment and evaluation in schools should be modified to suit the KWL strategy.

- It is necessary to provide the tools required by the KWL teaching strategy in UAE schools.

- Teachers should be encouraged to exchange visits and hold periodic meetings to discuss new teaching strategies such as the KWL strategy.

\section{LIMITATIONS OF THE RESEARCH}

Subject limitations: The study was limited to the second unit (Kingdoms of Living Things) of the science textbook, which was taught to students in the academic year 2017/2018.

Human limitations: The study was limited to fourth-grade students in primary stage at the Abu Obaida Bin Jarrah Private School in the Ajman region of the United Arab Emirates.

Spatial limitations: Abu Obaida Bin Jarrah Private School in the Ajman region of the United Arab Emirates.

Time limitations: Academic year 2018/2019/ first semester.

\section{REFERENCES}

Abu Youniss, M. (2013). The effectiveness of using (K.W.L) strategy on developing reading comprehension skills for the eighth graders in Khanyounis Governorate Schools, Department of Curricula and Teaching Methods (Unpublished Master thesis). Al-Azhar University-Gaza.

Ajzan, I. (1988). Attitudes, personality and behavior. Chicago: The Dorsey Press.

Akerson, V. (2001). Teaching science when your principal says, "Teach language arts." Science and Children, 38(7), $42-47$.

Akily, S. (2010). The impact of the use of meta-knowledge strategies in the teaching of science on achievement and knowledge skills and towards the subject of blind students. Journal of Studies in Curriculum and Instruction, 154, 26-66.

Aloraini, S. (2012). The impact of using multimedia on students' academic achievement in the college of Education at King Saud University. Journal of King Saud University Languages and Translation, 24, 75-82. https:// doi.org/10.1016/j.jksult.2012.05.002

Araam, M. (2012). The impact of using (K.W.L) strategy on acquiring the concepts and critical thinking skills of science subject for the seventh-grade student (MA thesis). The Islamic University of Gaza, Gaza.

Blachowicz, C., \& Ogle, D. (2008). Reading comprehension: Strategies for independent learners. New York: Guilford Press.

Bryan, J. (1998). K-W-L: Questioning the known. The Reading Teacher, 51(7), 618-620.

Camp, D. (2000). It takes two: Teaching with twin text of fact and fiction. The Reading Teacher, 53, 400-408.

Christo-Baker, E. (2004). College and university faculty attitude, incivilities and barriers towards distance education, (Unpublished Ph.D thesis), Bowling Green State University.

Conner, J. (2006). Advanced study of the teaching of secondary school reading instructional reading strategy: KWL (Know, Want to Learn, Learned). Retrieved from http:/ / www.indiana.edu/ 1517/KWL.htm

Ekwensi, F., Moranski, J., \& Townsend-Sweet, M. (2006). E-learning concepts and techniques. Bloomsburg University of Pennsylvania's Department of Instructional Technology.

Flavell, J. H. (1976). Metacognitive aspects of problem solving. In: L. B. Resnick (Ed.), The nature of intelligence. Hillsdale, Erlbaum.

Foote, C. J., Vermette, P. J., \& Battaglia, C. F. (2001). Constructivist strategies: Meeting standards and engaging adolescent minds. Larchmont: Eye on Education. 
Gammill, D. M. (2006). Learning to write way. The Reading Teacher, 59(8), 754-762. https://doi.org/10.1598/RT.59.8.3

Hayes, M. (2002). Elementary preservice teachers' struggles to define inquiry-based science Teaching. Journal of Science Teacher Education, 13(2), 147-165. https:/ / doi.org/10.1023/ A:1015169731478

Hershberger, K., \& Zembal-Saul, C. (2015). Methods and strategies: KLEWS to explanation-building in science. Science and Children, 52(6), 66-71. https://doi.org/10.2505/4/sc15_052_06_66

Hewitt, P. G. (1990). Conceptually speaking. Science Teacher, 57(5), 54-57.

Hyder, I., \& Bhamani, S. (2018). Bloom's Taxonomy (Cognitive Domain) in Higher Education Settings: Reflection Brief. Journal of Education and Educational Development, 3(2), 288-300. https://doi.org/10.22555/joeed.v3i2.1039

Ibrahim, N, N. (2012). The use of KWL technique in teaching reading descriptive text: A quasi-experimental study in the first grade of a senior high school in Bandung. Retrieved on 11 June 2018 from http:/ / aresearch.upi.edu/operator/upload/s_ing_0608702_chapter3.pdf

Jared, E. J., \& Jared, A. H. (1997). Launching into improved comprehension. The Technology Teacher, 56(6), 24-31.

Kishta, A. (2008). Effectiveness of using metacognitive strategies on developing scientific concepts and life skills of fifth-grade students in Gaza (Unpublished Master thesis in education). Faculty of Education, Islamic University, Gaza.

Kopp, K. (2010). Everyday content-area writing: Write-to-learn strategies for Grades 3-5 (1st ed.). Gainesville: Maupin House.

Kuhn, D., \& Dean, D. (2004). A bridge between cognitive psychology and educational practice. Theory into Practice, 43(4), 268-273. https:/ / doi.org/10.1207/s15430421tip4304_4

Lismayanti, R. (2014). The effect of using KWL (Know, Want, Learned) strategy on EFL students' reading comprehension achievement. International Journal of Humanities and Social Science, 4(7), 1.

Ministry of Education. (2015). UAE Education System. Retrieved on 21 September 2018 from https:/ / www.moe.gov.ae/En/Documents/The\%20FInal\%20MOE\%20Book\%20(1).pdf

Munck, M. (2007). Science pedagogy, teacher attitudes, and student success. Journal of Elementary Science Education, 19(2), 13-24. https:// doi.org/10.1007/BF03173660

Nagel, L., Blignaut, A. S., \& Cronjé, J. C. (2009). Readonly participants: A case for student participation in online classes. Interactive Learning Environments, 17(1), 37-51. https:/ / doi.org/10.1080/10494820701501028

Nair, T. S., \& Bindu, R. L. (2016). Effect of Blended Learning Strategy on Achievement in Biology and Social and Environmental Attitude of Students at Secondary Level. Journal on School Educational Technology, 11(4), 3952. (EJ1131827). https:/ / doi.org/10.26634/jsch.11.4.6011

Ogle, D. (2005). K-W-L + in action. In: H. Daniels \& M. Bizar (Eds.). Teaching the best practice way: Methods that matter, K-12. Portland, Stenhouse

Ogle, D. (2009). Creating contexts for inquiry: From KWL to PRC2. Knowledge Quest, 38(1), 56-61.

Piper, S. G. (1992). A metacognitive skills/reading comprehension intervention program for sixth-grade social studies students. (ERIC Document Reproduction Service ED 350 561).

Sasson, D. (2008). Use K-W-L technique in reading lessons: Strategic thought process for engaging students before they read. Retrieved from http:/ / newteachersupport.suite101.com/article.cfm

Schraw, G., \& Moshman, D. (1995). Metacognitive theories. Educational Psychology Review, 7(4), $351-371$. https:/ / doi.org/10.1007/BF02212307

Sinambela, E., Manik, S., \& Pangaribuan, R. (2015). Improving students' reading comprehension achievement by using K-W-L strategy. English Linguistics Research, 4(3). https:/ / doi.org/10.5430/elr.v4n3p13

Siribunnam, R., \& Tayraukham, S. (2009). Effects of 7-E, K.W.L and conventional instruction on analytical thinking, learning achievement and attitudes toward chemistry learning. Journal of Social Science, 4(5), 279-282. https://doi.org/10.3844/jssp.2009.279.282

Stahel, K. (2008). The Effects of Three Instructional Methods on the Reading Comprehension and Content Acquisition of Novice Readers. Journal of Literacy Research, 40(3), 359-393. https:/ / doi.org/10.1080/10862960802520594

Stahl, S., Sinatra, R., \& Gregory, J. (1991). The role of prior knowledge and vocabulary in reading comprehension. Georgia: Center for the Study of Reading, University of Georgia.

Steele, J., \& Dyer, T. (2014). Use of KWLs in the Online Classroom as It Correlates to Increased Participation. Journal of Instructional Research, 3, 8-14. 
Sumardiono, D. (2013). Using KWLH technique to understand local descriptive texts in teaching reading: Enhancing teachers' share through social media. Jurnal inovasi pendidikan, 1(2), 32-39.

Szabo, S. (2006). KWHHL: A student-driven evolution of the KWL. American Secondary Education, 34(3), 57-66.

Taslidere, E., \& Eryilmaz, A. (2012). The relative effectiveness of integrated reading study strategy and conceptual physics approach. Research in Science Education, 42(2), 181-199. https:/ / doi.org/10.1007/s11165-010-9194-1

Tok, S. (2008). The effects of note taking and K.W.L strategy on attitude and academic achievement. Hacettepe University. Journal of Education, 34, 244-253.

Weaver, C. (1994). Reading process and practice: From socio-psycholinguistics to whole language. Portsmouth, NH: Heinemann.

Zouhor, Z., Bogdanović, I., Skuban, S., \& Milica, P. (2017). The effect of the modified Know-Want-Learn strategy on sixth-grade students' achievement in physics. Journal of Baltic Science Education, 16(6). Retrieved from http:/ / www.scientiasocialis.lt/jbse/?q=node/ 624

\section{http://www.ejmste.com}

